\title{
Eco-physiological evaluation of different scion-rootstock combinations of almond grown in Mediterranean conditions
}

\author{
Jihène Ben Yahmed ${ }^{1, \star}$, Mohamed Ghrab ${ }^{2}$ and Mehdi Ben Mimoun ${ }^{1}$ \\ 1 Institut National Agronomique de Tunisie, 43 avenue Charles Nicolle, 1082, Tunis, Tunisie \\ 2 Institut de l'Olivier, B.P. 1087, Sfax, 3000, Tunisie
}

Received 20 July 2015 - Accepted 20 January 2016

\begin{abstract}
Introduction. Recent management trends in almond orchards have focused on intensification and highdensity plantings using Prunus rootstock cultivars with different vigor traits. This investigation aims to prospect precocious detection of adequate scion-rootstock combination for almond. Materials and methods. Five almond cultivars ('Tuono', 'Lauranne', 'Soleta', 'Belona' and 'Guara') grafted on three peach and plum based rootstocks of different degrees of vigor ('Garnem', 'Rootpac-40' and 'Rootpac-20') were trained in super high-density planting in an experimental orchard. Tree vigor, tree water status, leaf chlorophyll content and quantum yield of photosynthesis system II (PSII) were monitored over two budding seasons. Results and discussion. 'Garnem' and 'Rootpac-40' were respectively the most and the medium vigorous rootstocks and induced the best tree water status, chlorophyll content and quantum yield of PSII for the tested almond cultivars. Scions grafted on 'Garnem' had the highest values of trunk cross-sectional area (TCSA), and almond scions were higher on 'Garnem', intermediate on 'Rootpac-40' and lower on 'Rootpac-20'. Scions grafted on 'Rootpac-20' seemed to be the most dwarf phenotype. Moreover, 'Rootpac-20' performed the lowest values of stem water potential and showed various visual symptoms of chlorosis. Conclusion. Overall, 'Rootpac-40' exhibited a medium capacity to control tree vigor and well adapted to Mediterranean soil conditions.
\end{abstract}

Keywords: Tunisia / almond / Prunus dulcis / genetic resource evaluation / fruit tree vigor / orchard crop management / planting density

Résumé - Évaluation éco-physiologique des différentes combinaisons scion-porte-greffe d'amandiers cultivés en conditions méditerranéennes. Introduction. Les tendances récentes de gestion des vergers d'amandiers ont été à l'intensification et aux plantations de forte densité utilisant des cultivars de Prunus de différent type de vigueur comme porte-greffes. Cette étude vise à détecter de façon précoce les meilleures combinaisons scion-porte-greffe chez l'amandier. Matériel et méthodes. Cinq cultivars d'amandier ('Tuono', 'Lauranne', 'Soleta', 'Belona' et 'Guara') greffés sur trois porte-greffes à base de pêcher ou de prunier de différents niveaux de vigueur ('Garnem', 'Rootpac40' et 'Rootpac-20') ont été implantés dans un verger expérimental de super haute densité. La vigueur des arbres, leur état hydrique, le contenu en chlorophylle des feuilles et le rendement quantique du PSII ont été suivis pendant deux saisons de croissance. Résultats et discussion. 'Garnem' et 'Rootpac-40' ont été respectivement le porte-greffe le plus vigoureux et intermédiaire qui ont induit le meilleur état hydrique de l'arbre, la meilleure teneur en chlorophylle et le meilleur rendement quantique du PSII pour des cultivars d'amandier testés. Les scions greffés sur 'Garnem' avaient les plus hautes valeurs de section transversale du tronc (STT), et la croissance des scions d'amandier a été plus élevée sur 'Garnem', intermédiaire sur 'Rootpac-40' et faible sur 'Rootpac-20'. Les scions greffés sur 'Rootpac20 ' ont présentés les phénotypes les plus nains. De plus, 'Rootpac-20' a produit les plus faibles valeurs du potentiel hydrique de la tige et a montré différents symptômes visuels de chlorose. Conclusion. Globalement, 'Rootpac-40' a montré une capacité moyenne à contrôler la vigueur des arbres et semble bien adapté aux conditions de sol méditerranéen.

Mots clés : Tunisie / amandier / Prunus dulcis / évaluation du matériel génétique / vigueur des arbres fruitiers / densité de plantation / gestion du verger

\footnotetext{
^ Corresponding author: jihene.benyahmed@gmail.com
} 


\section{Introduction}

The adequate choice of the scion-rootstock combination is important in the adaptation of the fruit tree to specific training systems [1]. Different studies using Prunus spp. have demonstrated that the rootstock type may affect the performance of the grafted scion cultivar [2]. Rootstock may provide improved fruit quality and water use efficiency by altering stomata size, transpiration, water potential and vegetative growth [3,4]. Selecting the right scion-rootstock association is important for optimizing the chemical characteristics of fruit, especially sugar profile [5], yield, vigor and plant blooming [6]. Rootstocks may also confer tolerance to different biotic and abiotic stresses in the soil [7].

Recent trends in almond orchards have focused on intensification and high-density plantings, new cultivars and drip irrigation systems. This new planting system is justified by the need for mechanical harvesting and pruning. This system was first used in olive orchards and allowed for heavy cropping within a few years after planting and improving olive trees results with minimal soil maintenance, mechanical harvesting and pruning $[8,9]$. The new high-density planting system has been adopted in fruit tree orchards, such as almond. This may be possible through the use of rootstocks that promote reduced or moderate tree vigor, combined with new cultivars to achieve a high and early yield. Recently, less vigorous rootstocks were developed in Spain such as 'Rootpac ${ }^{\circledR}$ ' series, which enable the development of almond, peach, nectarine, plum and apricot crops [10]. 'Rootpac-40' and 'Rootpac-20' are considered to be less vigorous than 'Garnem', which opens the possibility to establish more efficient production systems in high-density orchards [11]. However, their adaptability to warm Mediterranean environments with the presence of soil borne pathogens and unfavorable soil conditions may limit their use [12]. Significant effects of insufficient chilling accumulation on peach cultivars were somewhat attenuated by rootstock type [13]. An experimental trial was established to evaluate the performance of different scion-rootstock combinations of almond under a new high-density planting system. It focused on the physiological response of three Prunus rootstocks with different degrees of vigor ('Garnem', 'Rootpac-20' and 'Rootpac-40') grafted with five almond cultivars in a warm Mediterranean area.

\section{Materials and methods}

\subsection{Experimental trial}

This study was carried out in an experimental orchard situated in the region of Mornag, northern Tunisia $\left(36^{\circ} 41^{\prime} \mathrm{N}\right.$, $10^{\circ} 15^{\prime} \mathrm{E}$ ). It focused on the agronomic performance of five almond cultivars ('Tuono', 'Lauranne', 'Soleta', 'Belona' and 'Guara') grafted on three rootstocks of different degrees of vigor ['Garnem' (Prunus dulcis $\times$ P. persica), 'Rootpac-40' $((P$. dulcis $\times P$. persica $) \times(P$. dulcis $\times P$. persica $))$ and 'Rootpac-20' (P. besseyi $\times$ P. cerasifera)] (table I).
The experimental site is characterized by a warm Mediterranean climate, with annual rainfall and reference evapotranspiration $\mathrm{ET}_{0}$ of 450 and $1,240 \mathrm{~mm}$, respectively, and a silty soil. The orchard is under drip irrigation and is subject to standard horticultural practices for production. Trees were obtained from Agromillora Iberia S.L. (Subirats, Barcelona, Spain) and grown for 12 months in a nursery under natural photoperiod conditions. Then, one-year trees were planted in June 2012 in the field at $4 \mathrm{~m} \times 1.5 \mathrm{~m}$ spacing for 'Rootpac20 ', and $4 \mathrm{~m} \times 2 \mathrm{~m}$ for 'Garnem' and 'Rootpac-40'. Trees were arranged in three blocks corresponding to the three rootstocks ('Garnem', 'Rootpac-40' and 'Rootpac-20'). Five almond cultivars ('Tuono', 'Lauranne', 'Soleta', 'Belona' and 'Guara') grafted on each rootstock were planted in parallel lines on a homogeneous field. For each line 50 trees of the same scion/rootstock combination were installed. Plants were subject to cultural practices for commercial orchards at high density planting. Climatic data analysis during our experiment revealed a warm winter with lack of chilling in 2014. Chilling accumulation was about 487 and 272 chill hours (CH) in 2013 and 2014, respectively, compared to the average of $478 \mathrm{CH}$ in this region.

\subsection{Tree physiology evaluation}

The performance of five almond cultivars on three rootstocks was evaluated during 2013 and 2014. Monitoring concerned vegetative growth, tree water status, leaf greenness and quantum yield of photosynthesis system II (PSII). Seven replications per scion-rootstock combination out of a total of 50 trees, located in the middle of the line, were assigned for the measurements. Three leaves per plant at the same height and at the same developmental stage were tagged randomly. These leaves were used for periodic measurement every 15 days from April to September 2014.

\subsubsection{Tree vigor}

Tree vigor of the different scion-rootstock combinations was evaluated by the trunk cross-sectional area (TCSA) at $20 \mathrm{~cm}$ high from the soil.

\subsubsection{Tree water status}

The water status of almond trees was measured every two weeks from May to August 2014 on seven trees from each scion-rootstock. The stem water potential $\left(\Psi_{\text {stem }}\right)$ was measured on mature leaves using a pressure chamber (PMS Instruments, Model 1000) from 12:00 to 14:00. It was determined on leaves enclosed in a black plastic covered with aluminum foil more than $2 \mathrm{~h}$ before measurements [14]. Three mature leaves per tree were used for each measurement.

\subsubsection{Leaf SPAD determination}

The chlorophyll content or leaf greenness was measured for each plant with the help of SPAD 502 meter (Minolta Co., 
Table I. List of the studied rootstocks (Prunus spp.) and almond cultivars (Prunus dulcis).

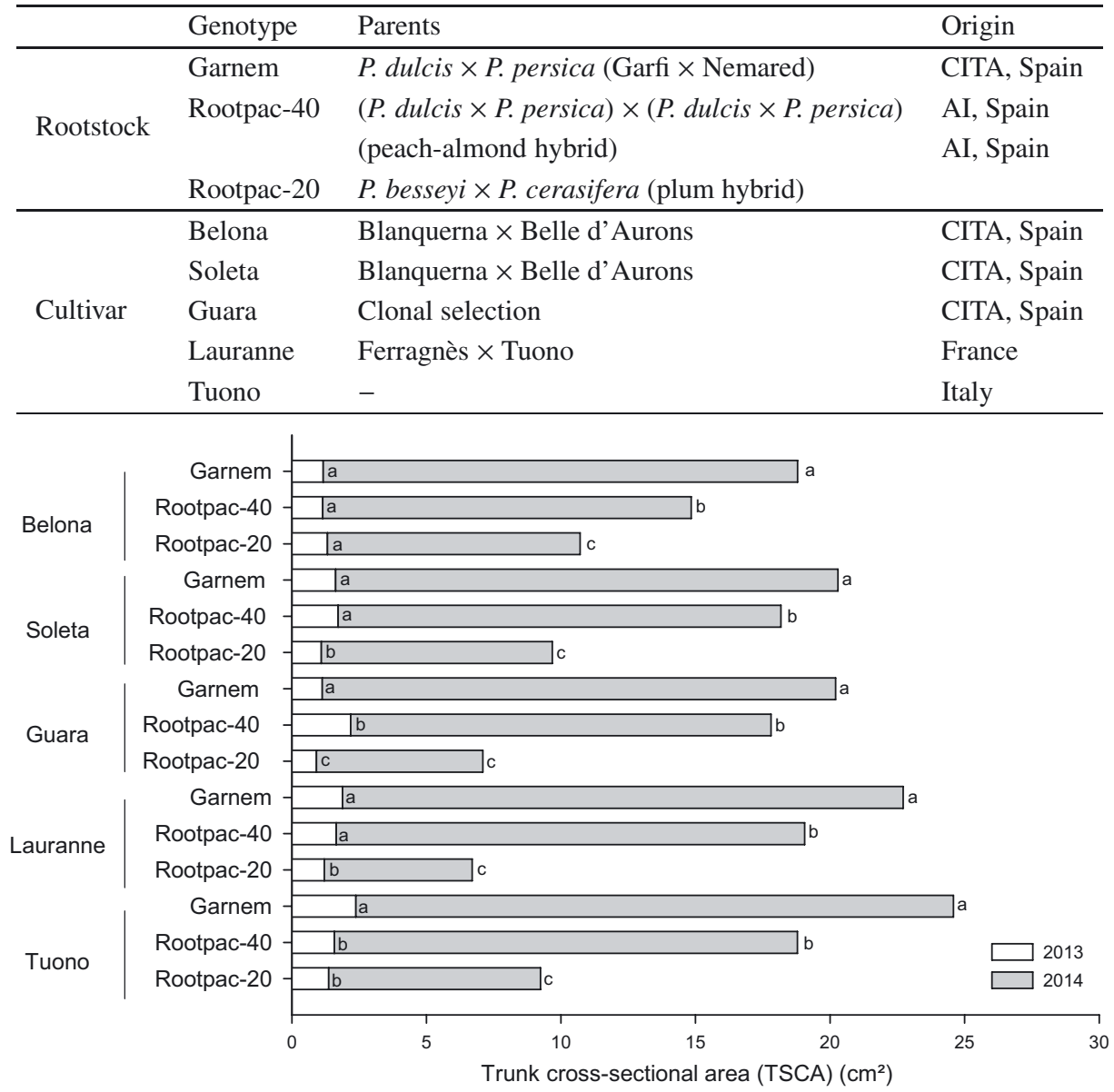

Figure 1. Trunk cross-sectional area $\left(\mathrm{cm}^{2}\right)$ of 15 scion-rootstock combinations determined at the end of 2013 and 2014 . Values with different letters were significantly different comparing different rootstock effects within each cultivar $(P \leqslant 0.05, n \geqslant 7)$.

Osaka, Japan). Monitoring was made on 21 leaves per each scion-rootstock combination (3 leaves from seven replications for each combination). For each leaf, measurements were performed on three different points (63 measurements made in total). Measurements were carried out every two weeks during the vegetative period. Measurements done by the end of May or the beginning of June (more than 60 days after full bloom) were taken into consideration.

\subsubsection{Quantum yield of PSII}

The effective quantum yield of photosystem II electron transport ( $\Phi$ PSII), which represents the electron transport efficiency between photosystems within light adapted leaves, was checked using a leaf fluorometer (Fluorpen FP100, Photos System Instrument). Three leaves per tree of the same height and at the same developmental stage were tagged randomly. These leaves were used for periodic measurement every 15 days from April to September 2014.

\subsection{Statistical analysis}

For statistical analysis, we used the software Statgraphics for Windows (version 4.1; Microsoft Corp., Redmond,
WA, USA) and SigmaPlot (Systat Software, San Jose, CA) for drawing the figures. The data are expressed as average \pm SE. An ANOVA was used to detect differences between scion/rootstock combinations. Statistical significance was set at $P \leqslant 0.05$.

\section{Results and discussion}

\subsection{Vegetative growth}

Tree vigor of almond cultivars was evaluated by measuring the trunk's cross-sectional area (TCSA) for two consecutive years. TCSA significantly changed depending on the rootstock genotype (figure 1) and differences were enhanced the second year. Higher values of TCSA were noted for cultivars grafted on 'Garnem' and 'Rootpac-40' compared to 'Rootpac-20'.

'Tuono', 'Lauranne' and 'Guara' showed the highest TCSA values when grafted onto 'Garnem' (2.37, 1.88 and $1.13 \mathrm{~cm}^{2}$, respectively) and 'Rootpac-40' (1.58, 1.65 and $2.19 \mathrm{~cm}^{2}$, respectively). Lower values were measured for the 'Belona' cultivar grafted on both rootstocks 'Rootpac-20' and 'Rootpac-40'. 
Almond is spreading nowadays in arid and semi arid regions of the Mediterranean Area. Irrigated orchards were extended during the last decades using auto-compatible cultivars budded on the vigorous rootstock 'GF677'. Some of them were established in arid conditions with very hot temperature and high evaporative demand [15]. In our experimental conditions, we observed different vigor levels in 3-year old trees with the higher on 'Garnem' and 'Rootpac-40' rootstocks. Based on trunk cross-sectional area (TCSA), tree vigor on 'Rootpac-40' was $25 \%$ less than on 'Garnem' and $50 \%$ more than on 'Rootpac-20'. 'Rootpac-20' illustrated the dwarfing effect through the significant slow growth of the trunk. Similarly, recent findings reported significantly lower performance of 'Rootpac-20' than 'Garnem' and 'Rootpac40 ', based on different vigor parameters, with $40-50 \%$ less vigor than 'GF677' [3].

The highest vigor was observed for the three new almond cultivars 'Soleta', 'Belona' and 'Guara' budded on 'Garnem' and for 'Tuono' and 'Lauranne' on 'Rootpac-40'. Socias i Company and Felipe [16] showed that 'Belona' and 'Soleta' presented medium vigor. The effect of 'Garnem' rootstock was already reported in field evaluation under Mediterranean conditions. It was found to be one of the high vigor reference rootstocks when budded with 'Tebana' peach and 'Queen Giant' nectarine cultivars [17]. 'Rootpac-40' exhibited a medium capacity to control tree vigor, presenting a medium vigor approximately 25-30\% less than 'GF677', while it had a very developed root system [11]. The mechanism by which rootstocks regulate scion vigor has not been clearly identified $[18,19]$. For peach and nectarine based rootstocks, vigor induction has been associated with hormonal relationships [19] and hydraulic conductance of roots and stems $[18,20]$. It was suggested that hormones may be involved to control scion growth, and a higher concentration of cytokinin was found in root exudates from vigorous rootstocks than from dwarfing ones [21]. Motisi et al. [20] reported lower tree stem water potential and lower hydraulic conductivity on dwarfing rootstocks than on vigorous rootstocks (such as 'GF677').

\subsection{Stem water potential}

Tree water status presented similar trends for the different scion-rootstock combinations of almond. There were

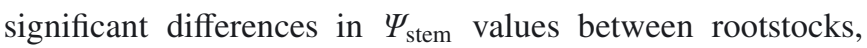
cultivar or scion-rootstock combinations (figure 2). Trees grafted on the less vigorous rootstock 'Rootpac-20' had unfavorable water status with a significant lower $\Psi_{\text {stem }}$ values. 'Garnem' and 'Rootpac-40' induced higher $\Psi_{\text {stem }}$ values. Trees on 'Rootpac-40' had $\Psi_{\text {stem }}$ values did not fall below $-2 \mathrm{MPa}$ with a maximum of $-0.8 \mathrm{MPa}$. A substantial decrease of $\Psi_{\text {stem }}$ was observed during the first week of June for all scion-rootstock combinations; as a response to higher climatic demand (figure 2), the lower $\Psi_{\text {stem }}$ values coincided with the time of maximum atmospheric evaporative demand. Under this difficult condition, $\Psi_{\text {stem }}$ decreased below -2 MPa. 'Lauranne' on 'Rootpac-20' seems to be the most affected cultivar with values reaching $-2.7 \mathrm{MPa}$ (figure 2).
In our experimental conditions, it appeared that 'Rootpac40' was the best adapted to the soil conditions of the experiment. It has been demonstrated that trees grafted on invigorating rootstocks have consistently presented higher $\Psi_{\text {stem }}$ than trees grafted on dwarfing rootstocks as reported for cherry $[22,23]$, peach $[3,18]$ and apple [24]. This phenomenon is likely to be related to the lower water absorption capability of the root system of dwarfing rootstocks to fulfill the transpiration demand of the canopy. In our case, stress problems have been observed for 'Rootpac-20'. This rootstock showed foliar desiccation associated with yellowing and leaf drop. This proves that, despite the dwarfing effect, this rootstock shows incompatibility or/and adaptation problems. It has been reported that the incompatibility problems are quite recurrent for plum based rootstocks. However, the good performance of the 'Rootpac-20' rootstock budded with peach cultivars [11] in colder areas with high chilling requirements of the Mediterranean area could indicate that this rootstock could be suffering from lack of chilling in Tunisian warmer conditions.

\subsection{Estimation of leaf greenness}

The leaf greenness estimated using the SPAD unit was significantly affected by rootstocks. The most important SPAD values were observed for trees grafted on 'Garnem' and the lowest values on 'Rootpac-20'. The highest value of the 47 unit SPAD was reached by the end of the vegetative growth for the almond cultivar 'Belona' on 'Garnem' (figure 3). 'Tuono' and 'Soleta' showed a similar behavior when grafted on 'Rootpac-40' and 'Garnem'. Otherwise, 'Rootpac-40' induced intermediate SPAD values and the most dwarfing rootstock 'Rootpac-20' had the significantly lowest SPAD values.

The indirect measurement of leaf greenness by SPAD readings has been used as an indicator of iron chlorosis tolerance in Prunus trees [25]. 'Garnem' and 'Rootpac-40' induced higher SPAD values in leaves, whereas 'Rootpac-20' showed the lowest SPAD values with clear visual symptoms of stress (values under 32 units SPAD). The results obtained were confirmed by those found by Mestre et al. [26], which concluded that the good adaptation of the rootstock to the growing conditions probably favored higher vigor, as well as higher $\mathrm{N}$ leaf content and SPAD values. Similarly, Jiménez et al. [3] showed that 'Rootpac-20' rootstock presented lower leaf chlorophyll concentration than 'GF677' and 'Rootpac ${ }^{\circledR} \mathrm{R}^{\prime}$. Pinochet [27] classified rootstocks as susceptible to iron chlorosis for values below 35 units SPAD. 'Garnem' and 'Rootpac-40' rootstocks can be classified as tolerant to iron chlorosis with high SPAD values.

The results obtained reflect a poor capacity of 'Rootpac20 ' in these field conditions to maintain SPAD values and seem to be sensitive to Mediterranean soil conditions. We found that the results were inconsistent with those of Jiménez et al. [11] who claimed that 'PAC 9801-02' ('Rootpac-20') was among the best adapted to soil sickness and calcareous soil conditions showing a good agronomic performance. This can be explained by differences in Mediterranean soil and climatic conditions. The use of several plum based species as rootstocks for peach and almond species may present 

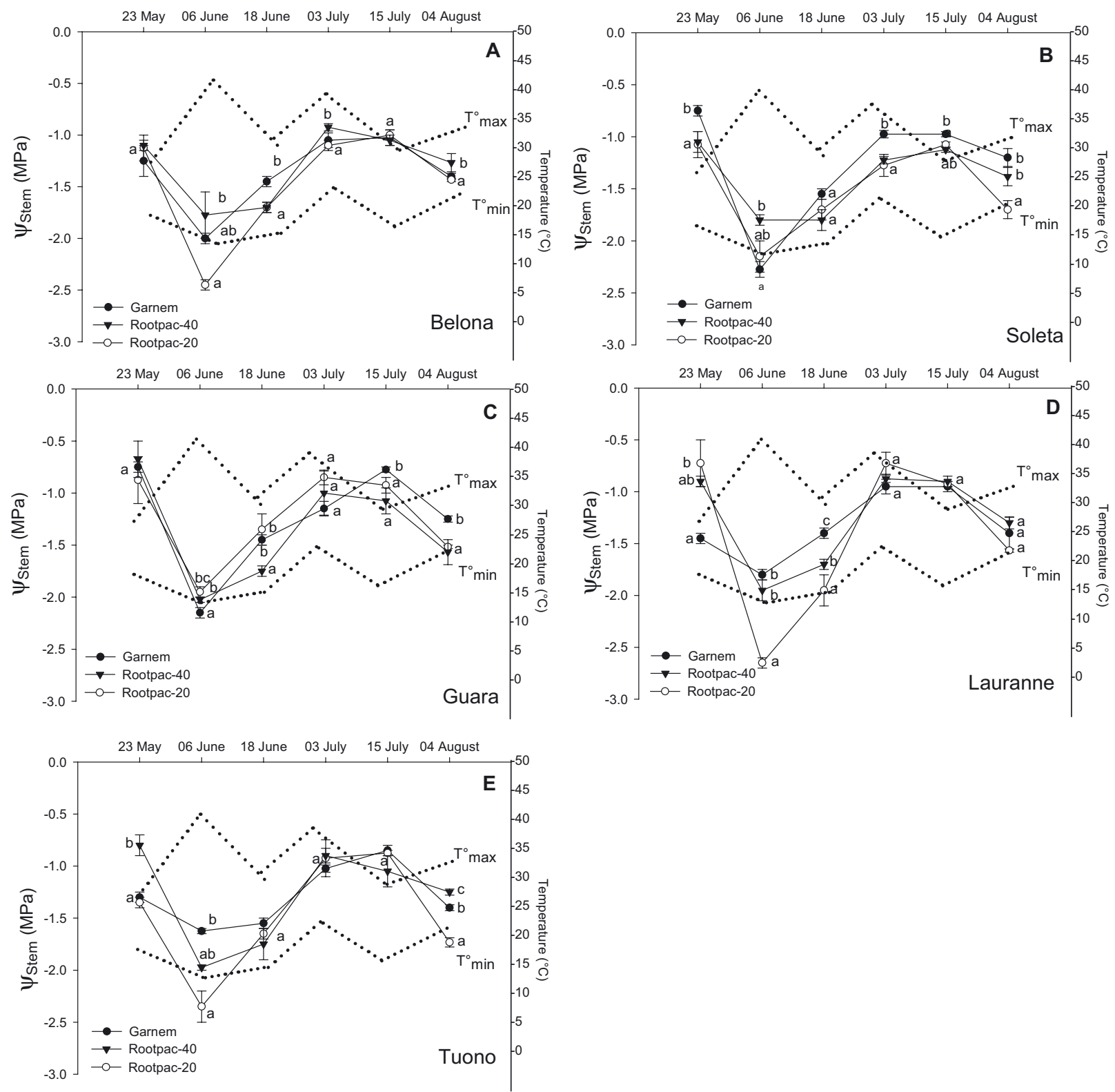

Figure 2. Stem water potential ( $\left.\Psi_{\mathrm{Stem}}\right)(\mathrm{MPa})$ of five almond cultivars grafted on three rootstocks with different degrees of vigor ('Garnem', 'Rootpac-40' and 'Rootpac-20') and daily maximum and minimum temperatures ( $\left.\mathrm{T}^{\circ} \mathrm{max}, \mathrm{T}^{\circ} \mathrm{min}\right)$ recorded from May to August 2014 at the almond experimental field. Values (means \pm standard errors) with different letters were significantly different $(P \leqslant 0.05, n \geqslant 3)$; A: 'Belona', B: 'Soleta', C: 'Guara', D: 'Lauranne' and E: ‘Tuono'.

graft-incompatibility [28] and root suckering, although good compatibility and agronomic performance is usually found when $P$. domestica and $P$. insititia plums are used $[26,29,30]$.

\subsection{Quantum yield of PSII}

Changes in value of quantum yield of PSII were observed during the growing season for all scion-rootstock combinations (figure 4). There were significant differences in the $\mathrm{F}_{\mathrm{v}} / \mathrm{F}_{\mathrm{m}}$ between rootstocks and [cultivar $\times$ rootstock] combinations. The highest overall values were observed for 'Guara' (min 0.47; $\max 0.62$ ) and 'Tuono' (min 0.45; $\max 0.63$ ) (figure 4).
For other cultivars, changes were more important. Comparing the rootstocks, the lowest amounts of chlorophyll fluorescence were observed for 'Rootpac-20'. For this rootstock, values were below 0.52. 'Garnem' and 'Rootpac-40' presented a similar performance with a higher value.

Lower values of quantum yield $\left(\mathrm{F}_{\mathrm{v}} / \mathrm{F}_{\mathrm{m}}\right)$ are measured for almond trees on 'Rootpac-20'. This result confirms that the rootstock type has an influence on PSII efficiency [31]. The slight reductions in $\mathrm{F}_{\mathrm{v}} / \mathrm{F}_{\mathrm{m}}$ occurred for almond cultivars on dwarfing rootstocks, indicating that down-regulation of PSII efficiency was associated with a protective increase in non-radiative dissipation of light energy [32]. Consequently, it seems that the dwarfing rootstock 'Rootpac-20' suffered 

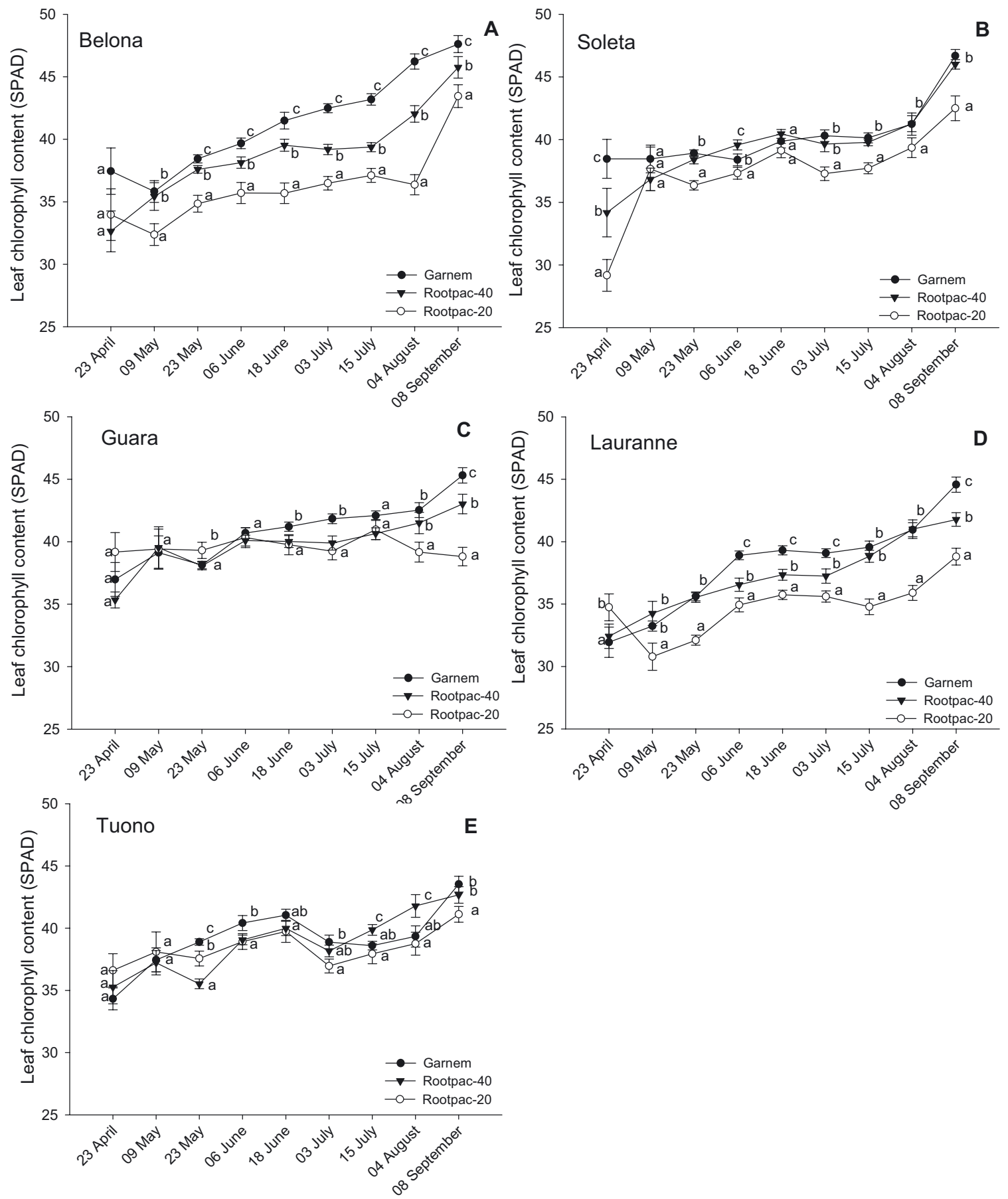

Figure 3. Leaf chlorophyll content (SPAD unit) of five almond cultivars grafted on three rootstocks with different degrees of vigor ('Garnem', 'Rootpac-40' and 'Rootpac-20') measured on 2014; A: 'Belona', B: 'Soleta', C: 'Guara', D: 'Lauranne' and E: 'Tuono'. Values (means \pm standard errors) with different letters were significantly different $(P \leqslant 0.05, n \geqslant 7)$.

from water stress under Mediterranean conditions and when the irrigation frequency was increased from winter to summer, it showed stress symptoms such as leaf fall and yellowing. This fact suggests that this rootstock presents a worse osmotic adjustment than 'Rootpac-40' and 'Garnem' to maintain leaf cell turgor. The decline in leaf cell turgor limits $\mathrm{CO}_{2}$ diffusion and reduces the quantum yield of PSII, which, in turn, may induce photorespiration and $\mathrm{H}_{2} \mathrm{O}_{2}$ production [33].
Jiménez et al. [3] found that the most vigorous rootstocks 'GF677' and 'Rootpac ${ }^{\circledR} \mathrm{R}$ ' induced higher water use efficiency. The capacity of avoiding water loss via transpiration is related to the tolerance of rootstocks to water shortage [34]. However, the dwarfing rootstock 'Rootpac-20' presented a lower tolerance capacity with an impaired photosynthetic capacity and seemed to be less efficient than 'Rootpac-40' and 'Garnem' despite its lower vigor. Anatomical differences in 

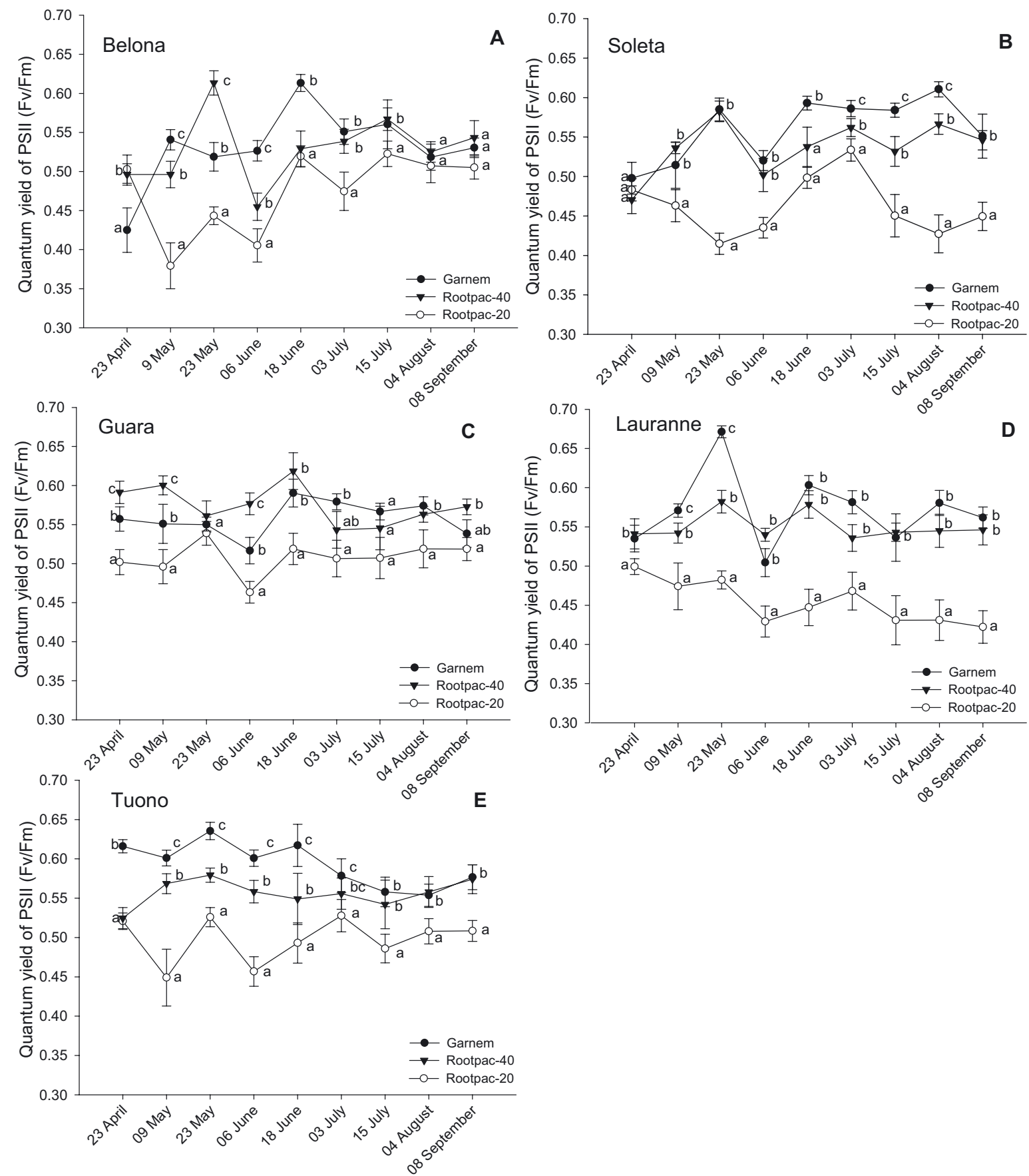

Figure 4. Quantum yield of PSII $\left(\mathrm{Q}_{\mathrm{y}}\right)(\mathrm{Fv} / \mathrm{Fm})$ of five almond cultivars grafted on three rootstocks with different degrees of vigor ('Garnem', 'Rootpac-40' and 'Rootpac-20') measured on 2014; A: 'Belona', B: 'Soleta', C: 'Guara', D: 'Lauranne' and E: 'Tuono'. Values (means \pm standard errors) with different letters were significantly different $(P \leqslant 0.05, n \geqslant 7)$.

stems induced by different degrees of vigor of cherry rootstocks may confirm this observation [4]. It is noteworthy that 'Rootpac-20' grafted with a late peach cultivar in a temperate climate condition in Teruel (West of Spain), outperformed all the other rootstocks in a field trial in production efficiency and fruit size [11]. In spite of the fact that rootstock was grafted with a different species cultivar, this could indicate the best adaptation of 'Rootpac-20' to cooler environments with high chill requirements.

\section{Conclusion}

The study reveals the effect of Prunus rootstocks with different degrees of vigor on almond cultivars trained according to a high-density planting system in a warm production area, two years after budding. In these growing conditions, 'Garnem' induced the highest tree vigor and a good tree water status. 'Rootpac-20' was the most dwarfing rootstock but presented problems of leaf yellowing and very low stem 
water potential. Overall, 'Rootpac-40' was well adapted to Mediterranean soil conditions showing a good agronomic performance (higher stem water potential values) and exhibited an intermediate capacity to control tree vigor.

Low vigor could be associated to a higher yield efficiency that is making it ideal for high density orchards with the benefits of reducing labor costs, especially for pruning and harvest. However, in warm Tunisian conditions, the most dwarfing rootstock 'Rootpac-20' could suffer from inadequate chilling, resulting in bad adaptation, which is potentially problematic with the current global warming trend.

Acknowledgements. We wish to thank the Sadira Company for providing the experimental field. We gratefully acknowledge the great help in the revision of the manuscript to Dr. Maria Angeles Moreno from the 'Departamento de Pomología, Estación Experimental de Aula Dei' (EEAD-CSIC), Spain and Dr. Raphael Morillon from the research team 'Improvement of vegetatively propagated plants' (APMV), Department BIOS, CIRAD, Station de Roujol, Guadeloupe, France. The authors gratefully acknowledge the great help in English revision of the manuscript to Wanderlust International Language Center (WILC).

\section{References}

[1] DeJong T., Johnson R., Doyle J., Ramming D., Labor costs may be reduced... Research yields size-controlling rootstocks for peach production, Calif. Agric. 59 (2005) 80-83.

[2] Font i Forcada C., Gogorcena Y., Moreno M.Á., Agronomical and fruit quality traits of two peach cultivars on peach-almond hybrid rootstocks growing on Mediterranean conditions, Sci. Hortic. 140 (2012) 157-163.

[3] Jiménez S., Dridi J., Gutiérrez D., Moret D., Irigoyen J.J., Moreno M.Á., Gogorcena Y., Physiological, biochemical and molecular responses in four Prunus rootstocks submitted to drought stress, Tree Physiol. 33 (2013) 1061-1075.

[4] Hajagos A., Végvári G., Investigation of tissue structure and xylem anatomy of eight rootstocks of sweet cherry (Prunus avium L.), Trees 27 (2013) 53-60.

[5] Font i Forcada C., Gogorcena Y., Moreno M., Fruit sugar profile and antioxidants of peach and nectarine cultivars on almond $\times$ peach hybrid rootstocks, Sci. Hortic. 164 (2013) 563-572.

[6] Weibel A., Johnson R.S., DeJong T.M., Comparative vegetative growth responses of two peach cultivars grown on sizecontrolling versus standard rootstocks, J. Am. Soc. Hortic. Sci. 128 (2003) 463-471.

[7] Balal R.M., Khan M.M., Shahid M.A., Mattson N.S., Abbas T., Ashfaq M., Garcia-Sanchez F., Ghazanfer U., Gimeno V., Iqbal Z., Comparative studies on the physiobiochemical, enzymatic, and ionic modifications in salt-tolerant and salt-sensitive Citrus rootstocks under $\mathrm{NaCl}$ stress, J. Am. Soc. Hortic. Sci. 137 (2012) 86-95.

[8] Connor D.J., Gómez-del-Campo M., Rousseaux M.C., Searles P.S., Structure, management and productivity of hedgerow olive orchards: a review, Sci. Hortic. 169 (2014) 71-93.

[9] Tous J., Romero A., Hermoso J., New trends in olive orchard design for continuous mechanical harvesting, Adv. Hortic. Sci. 24 (2010) 43-52.
[10] Pinochet J., 'Greenpac', a New Peach Hybrid Rootstock Adapted to Mediterranean Conditions, HortScience 44 (2009) 1456-1457.

[11] Jiménez S., Pinochet J., Romero J., Gogorcena Y., Moreno M.Á., Espada J.L., Performance of peach and plum based rootstocks of different vigour on a late peach cultivar in replant and calcareous conditions, Sci. Hortic. 129 (2011) 58-63.

[12] Pinochet J., Cunill M., Torrents J., Eremin G., Eremin V., Nicotra A., Penyalver R., López M., Jiménez Tarodo S., Gogorcena Aoiz Y., Response of low and medium vigour rootstocks for peach to biotic and abiotic stresses, Acta Hortic. 962 (2012) 627-632.

[13] Ghrab M., Ben Mimoun M., Masmoudi M.M., Ben Mechlia N., Chilling trends in a warm production area and their impact on flowering and fruiting of peach trees, Sci. Hortic. 178 (2014) 87-94.

[14] Shackel K., Gurusinghe S., Kester D., Micke W., Water stress responses of almond [Prunus dulcis (Mill.) Webb.] trees under field conditions, Acta Hortic. 470 (1998) 309-316.

[15] Felipe A.J., 'Felinem', 'Garnem', and 'Monegro'almond $\times$ peach hybrid rootstocks, HortScience 44 (2009) 196-197.

[16] Socias i Company R., Felipe A.J., 'Belona'and 'Soleta' Almonds, HortScience 42 (2007) 704-706.

[17] Zarrouk O., Gogorcena Y., Gómez-Aparisi J., Betrán J.A., Moreno M.A., Influence of almond $\times$ peach hybrids rootstocks on flower and leaf mineral concentration, yield and vigour of two peach cultivars, Sci. Hortic. 106 (2005) 502-514.

[18] Basile B., Marsal J., DeJong T.M., Daily shoot extension growth of peach trees growing on rootstocks that reduce scion growth is related to daily dynamics of stem water potential, Tree Physiol. 23 (2003) 695-704.

[19] Sorce C., Massai R., Picciarelli P., Lorenzi R., Hormonal relationships in xylem sap of grafted and ungrafted Prunus rootstocks, Sci. Hortic. 93 (2002) 333-342.

[20] Motisi A., Pernice F., Sottile F., Caruso T., Rootstock effect on stem water potential gradients in cv. 'Armking' nectarine trees, Acta Hortic. 658 (2004) 75-79.

[21] Vazifeshenas M., Khayyat M., Jamalian S., Samadzadeh A., Effects of different scion-rootstock combinations on vigor, tree size, yield and fruit quality of three Iranian cultivars of pomegranate, Fruits 64 (2009) 343-349.

[22] Gonçalves B., Santos A., Silva A., Moutinho-Pereira J., TorresPereira J., Effect of pruning and plant spacing on the growth of cherry rootstocks and their influence on stem water potential of sweet cherry trees, J. Hortic. Sci. Biotechnol. 78 (2003) 667-672.

[23] Schmitt E., Duhme F., Schmid P., Water relations in sweet cherries (Prunus avium L.) on sour cherry rootstocks (Prunus cerasus L.) of different compatibility, Sci. Hortic. 39 (1989) 189-200.

[24] Olien W.C., Lakso A.N., Effect of rootstock on apple (Malus domestica) tree water relations, Physiol. Plant. 67 (1986) 421-430.

[25] Jiménez S., Pinochet J., Abadía A., Moreno M.Á., Gogorcena Y., Tolerance response to iron chlorosis of Prunus selections as rootstocks, HortScience 43 (2008) 304-309.

[26] Mestre L., Reig G., Betrán J.A., Pinochet J., Moreno M.Á., Influence of peach-almond hybrids and plum-based rootstocks on mineral nutrition and yield characteristics of 'Big Top'nectarine in replant and heavy-calcareous soil conditions, Sci. Hortic. 192 (2015) 475-481. 
[27] Pinochet J., 'Replantpac' (Rootpac ${ }^{\circledR}$ R), a Plum-almond Hybrid Rootstock for Replant Situations, HortScience 45 (2010) 299-301.

[28] Zarrouk O., Testillano P.S., Risueño M.C., Moreno M.Á., Gogorcena Y., Changes in cell/tissue organization and peroxidase activity as markers for early detection of graft incompatibility in peach/plum combinations, J. Am. Soc. Hortic. Sci. 135 (2010) 9-17.

[29] Font i Forcada C., Gogorcena Y., Moreno M.Á., Agronomical parameters, sugar profile and antioxidant compounds of "Catherine" peach cultivar influenced by different plum rootstocks, Int. J. Mol. Sci. 15 (2014) 2237-2254.

[30] Gómez Aparisi J., Loìpez Guerrero V., Felipe A., Carrera M., Graft compatibility study of 'Montizo' and 'Monpol' pollizo plum as a rootstock for almond, Acta Hortic. 591 (2002) $105-107$.
[31] Losciale P., Oguchi R., Hendrickson L., Hope A.B., CorelliGrappadelli L., Chow W.S., A rapid, whole-tissue determination of the functional fraction of PSII after photoinhibition of leaves based on flash-induced P700 redox kinetics, Physiol. Plant. 132 (2008) 23-32.

[32] Oberhuber W., Bauer H., Photoinhibition of photosynthesis under natural conditions in ivy (Hedera helix L.) growing in an understory of deciduous trees, Planta 185 (1991) 545-553.

[33] Chaves M., Flexas J., Pinheiro C., Photosynthesis under drought and salt stress: regulation mechanisms from whole plant to cell, Ann. Bot. 103 (2009) 551-560.

[34] Alarcón J., Sánchez-Blanco M.J., Nicolás E., Egea J., Dicenta F., Effects of drought on shoot water relations in 'Antoñeta' and 'Marta' almond cultivars grafted onto 'Garrigues' and 'GF677' rootstocks, Acta Hortic. 591 (2002) 345-349.

Cite this article as: Jihène Ben Yahmed, Mohamed Ghrab, Mehdi Ben Mimoun. Eco-physiological evaluation of different scion-rootstock combinations of almond grown in Mediterranean conditions. Fruits 71 (2016) 185-193. 